Running head: Ecological consequences of forest restoration treatments in Colorado

\title{
Short-term ecological consequences of collaborative restoration treatments in ponderosa pine forests of Colorado
}

Jennifer S. Briggs ${ }^{1}$, Paula J. Fornwalt ${ }^{2}$, and Jonas A. Feinstein ${ }^{3}$

1. Geosciences and Environmental Change Science Center, US Geological Survey, MS 980, Building 25, Denver Federal Center, Denver, CO 80225. Email: jsbriggs@ usgs.gov (Corresponding author)

2. USDA Forest Service, Rocky Mountain Research Station, 240 West Prospect Road, Fort Collins, CO 80526. Email: pfornwalt@fs.fed.us

3. USDA National Resource Conservation Service, Building 56, Denver Federal Center, Denver, CO 80225. Email: jonas.feinstein@ co.usda.gov

Submitted to: Forest Ecology and Management 10/14/16

Key words: Collaborative adaptive monitoring; ecological restoration; Collaborative Forest Landscape Restoration Program (CFLRP); ponderosa pine (Pinus ponderosa); treatment response 
Running head: Ecological consequences of forest restoration treatments in Colorado

\section{Abstract}

Ecological restoration treatments are being implemented at an increasing rate in ponderosa pine and other dry conifer forests across the western United States, via the USDA Forest Service's

Collaborative Forest Landscape Restoration (CFLR) program. In this program, collaborative stakeholder groups work with National Forests (NFs) to adaptively implement and monitor ecological restoration treatments intended to offset the effects of many decades of anthropogenic stressors. We initiated a novel study to expand the scope of treatment effectiveness monitoring efforts in one of the first CFLR landscapes, Colorado's Front Range. We used a Before/After/Control/Impact framework to evaluate the short-term consequences of treatments on numerous ecological properties. We collected pre-treatment and one year post-treatment data on NF and partner agencies' lands, in 66 plots distributed across seven treatment units and nearby untreated areas. Our results reflected progress toward several treatment objectives: treated areas had lower tree density and basal area, greater openness, no increase in exotic understory plants, no decrease in native understory plants, and no decrease in use by tree squirrels and ungulates. However, some findings suggested the need for adaptive modification of both treatment prescriptions and monitoring protocols: treatments did not promote heterogeneity of stand structure, and monitoring methods may not have been robust enough to detect changes in surface fuels. Our study highlights both the effective aspects of these restoration treatments, and the importance of initiating and continuing collaborative science-based monitoring to improve the outcomes of broad-scale forest restoration efforts.

\section{Introduction}

Wildfires are increasing in frequency, extent, and severity throughout dry conifer forests of the western United States (US; Westerling 2006; Jolly et al. 2014; Robichaud et al. 2014), 
Running head: Ecological consequences of forest restoration treatments in Colorado

highlighting a need for proactive management actions to increase social and ecological resilience to these events (North et al. 2015; Smith et al. 2016). Fuels reduction treatments have been conducted for many decades to decrease the probability of large, severe wildfires in these forests, which have been widely altered by anthropogenic land use practices and changes in climate (Cooper 1960; Hunter et al. 2007; Stephens et al. 2012). More recently, there has been an emphasis on implementing treatments with broader ecological restoration objectives (e.g., Covington et al. 1997; Brown et al. 2001; Allen et al. 2002; Youngblood et al. 2006; Korb et al. 2012; Fiedler et al. 2010; Underhill et al. 2014; Stephens et al. 2015). Restoration treatments are designed to address the ecological degradation that has been caused by anthropogenic stressors (SER 2004; Fulé et al. 2006); they aim to create more characteristic and disturbance-resilient conditions that are defined in terms of ecological structure and function (Moore et al. 1999; Allen et al. 2002; Larson \& Churchill 2012). Typical outcomes of such restoration treatments in dry conifer forests of the western US include reduced risk of high-severity fire across large areas, as well as a more open and heterogeneous forest structure, greater diversity and cover of native understory plants, and greater diversity of habitats for native wildlife species (e.g., Reynolds et al. 2013; Hessburg et al. 2015).

In 2010, the USDA Forest Service (USFS) initiated the national Collaborative Forest Landscape Restoration (CFLR) program to increase the pace and scale of ecological restoration efforts in western dry conifer and other degraded forests over the next 10 years (www.fs.fed.us/restoration/CFLRP). The program awarded up to $\$ 4$ million USD annually to selected National Forests (NFs) working with collaborative stakeholder groups in landscapes with a pressing need for restoration (Schultz et al. 2012). The expectations and budget of the 
Running head: Ecological consequences of forest restoration treatments in Colorado

program included monitoring the effectiveness of the restoration treatments, but for each of the CFLR-funded projects, the NFs and their collaborators were charged with developing their own monitoring programs (Schultz et al. 2014). Few precedents existed to guide the CFLR projects in this endeavor. The monitoring approach utilized by the Fire and Fire Surrogate study (FFS) at 12 sites across the US had some relevance, but FFS treatments tended to emphasize fuels reduction rather than ecological restoration, were implemented in 'blocks' with replicated but relatively small treatment and control units $(\sim 10 \mathrm{ha})$ at each site, and were monitored in a relatively standard manner across the sites (Schwilk et al. 2009; Stephens et al. 2012). Numerous other studies have evaluated the effects of restoration treatments on specific ecological properties and processes in western dry conifer forests (e.g., overstory density, Waltz et al. 2003; overstory spatial heterogeneity, Larson \& Churchill 2012; understory plants, Moore et al. 2006; birds, Gaines et al. 2007; mammals, Kalies et al. 2012; invertebrates, Waltz \& Covington 2003; and fuel loads, Fulé et al. 2006); however, few have simultaneously evaluated effects on a diverse suite of collaboratively-identified properties and processes (Thomas \& Waring 2014).

The Front Range of the southern Rocky Mountains in Colorado was one of the first landscapes in the US to receive CFLR funding in 2010. Large, uncharacteristically severe wildfires occurred in the area in 1996, 2000, and 2002 (Sherriff et al. 2014; Fornwalt et al. 2016), with considerable negative social and ecological impacts (Bhandary \& Muller 2009; Fornwalt et al. 2010; Rhoades et al. 2011; Chambers et al. 2016). These fires catalyzed both a regional fuels reduction effort and the identification of priority landscapes for restoration by a collaborative stakeholder group, the Front Range Roundtable (FRRT; Brown et al. 2001; Culver et al. 2001; FRFTP 2006). However, relatively few treatments with specifically restoration-oriented objectives were 
Running head: Ecological consequences of forest restoration treatments in Colorado

72 conducted due to limited budgets (Worden \& Kleier 2012; Keeley et al. 2013; Ertl 2015). In

73 2010, the Arapaho-Roosevelt and Pike-San Isabel NFs worked with the FRRT on a successful

74 application to the CFLR program for funding of restoration treatments across 12,950 ha of NF

75 land designated as highest priority for restoration within the larger 323,750-ha forested landscape

76 (Underhill et al. 2014; Cheng et al. 2015). As the NFs and their collaborators, collectively

77 referred to as the Colorado Front Range Landscape Restoration Initiative (CFRLRI; Underhill et

78 al. 2014), prepared to implement and monitor the CFLR-funded treatments, they expressed

79 numerous questions and concerns regarding the treatments' short- and long-term ecological

80 effects (Schultz et al. 2014; Dickinson et al. 2016).

82 In coordination with the CFRLRI, we initiated a study in 2011 to evaluate the short-term effects

83 of forest restoration treatments in Colorado's Front Range on several diverse ecosystem

84 components: forest stand- and patch structure; tree regeneration; surface fuels; understory plants;

85 and wildlife use. Several aspects of our study represented important expansions of the

86 monitoring effort planned by the CFRLRI with the budget allocated by the NFs (Clement \&

87 Brown, 2011). The original monitoring plan focused on measuring changes in forest stand

88 structure, surface fuels, and tree regeneration in NF treatment units, pre- and post-treatment, via

89 USFS Common Stand Exam (CSE) protocols (Clement \& Brown 2011; USDA Forest Service

90 2011). By leveraging supplemental funding, our study was able to extend the scope of the

91 monitoring program in three key ways. First, we included sites on other agencies' lands so that

92 inferences could be extended beyond the NFs. Second, we established pre- and post-treatment

93 monitoring plots not only in treatment units but also in nearby areas not scheduled for treatment,

94 thereby enabling a Before/After/Control/Impact study design (BACI; Stewart-Oaten et al. 1986) 
Running head: Ecological consequences of forest restoration treatments in Colorado

107 Methods

108 Study design

109 Our study was conducted in three study areas along Colorado's Front Range (Table 1). One 110

that could better evaluate treatment effectiveness (Hutto \& Belote 2013). Third, we supplemented the CSE protocols with new methods to monitor several additional aspects of the ecosystem - understory plants, wildlife use, and forest patch structure - that the CFRLRI found important but had not included in their original monitoring plan due to budget constraints. In this paper, we report on the ecological outcomes of the restoration treatments as well as on the role of our study in both the adaptive management (DeLuca et al. 2010) and adaptive monitoring (Lindenmayer \& Likens 2009) processes. The multiple goals of this project lend it relevance not only to the CFRLRI and the other 22 currently-funded CFLR landscapes, but to many of the additional collaborative restoration and monitoring efforts developing locally, nationally, and internationally in recent years (e.g., Pistorius \& Freiberg 2014 and references therein; JCLRP 2016). study area was located on Boulder County Parks and Open Space land (Heil Ranch; 40 10' N, $105^{\circ} 18^{\prime} \mathrm{W}$ ), one was located on the Roosevelt NF (Estes Valley; $40^{\circ} 16^{\prime} \mathrm{N}, 105^{\circ} 24^{\prime} \mathrm{W}$ ), and one was located on the Pike NF (Phantom Creek; 39 $3^{\prime} \mathrm{N}, 105^{\circ} 12^{\prime} \mathrm{W}$ ). Elevations at the study areas averaged approximately $2200 \mathrm{~m}$ at Heil Ranch, $2650 \mathrm{~m}$ at Estes Valley, and $2830 \mathrm{~m}$ at Phantom Creek. Forest overstories at the study areas were dominated or co-dominated by ponderosa pine (Pinus ponderosa), with varying proportions of additional overstory species such as Douglas-fir (Pseudotsuga menziesii), Rocky Mountain juniper (Juniperus scopulorum), and aspen (Populus tremuloides) at lower elevation study areas, and lodgepole pine (Pinus contorta), 
Running head: Ecological consequences of forest restoration treatments in Colorado

118

119

120

121

122

123

124

125

126

127

128

129

130

131

132

133

134

135

136

137

138

139

140

subalpine fir (Abies lasiocarpa), blue spruce (Picea pungens), Engelmann spruce (Picea engelmanii), and aspen at higher elevation study areas.

Each of the three study areas contained two to three study sites that consisted of a treatment unit and a nearby paired area not slated for treatment (Table 1). Treatment units ranged in size from approximately 30 to 140 ha. Treatment prescriptions were developed by the respective land management agencies and were necessarily variable due to pre-treatment site conditions, agency regulations, and treatment methods (Fig. 1), but all had the overall goal of meeting ecological restoration objectives and all involved thinning of the forest overstory via specialized machinery or hand crews (Underhill et al. 2014; Nick Stremel, Boulder County Parks and Open Space, Boulder, Colorado, personal communication). Untreated stands were located within $1 \mathrm{~km}$ of treatment units, in comparably-sized areas with similar aspect, slope, elevation, soils, and pretreatment overstory composition and structure.

Plot locations in the treatment units were determined by first visiting coordinates of existing CSE monitoring plots and identifying whether they met the criteria for inclusion in the study (below). If additional plot locations were needed for our study, we subsequently visited coordinates generated using a randomized method in a Geographic Information System (GIS). Because our study focused on evaluating changes in forested stands in ponderosa pine-dominated ecosystems, our criteria for plot selection were that plots contained at least five trees (within a variable-radius plot established using a Basal Area Factor (BAF) of 10, as described below), had at least one ponderosa pine $>1.37 \mathrm{~m}$ tall, were $>250 \mathrm{~m}$ from any other established plot and $>20 \mathrm{~m}$ from a unit edge, and had not been recently disturbed. If these criteria were met at a given location, we 
Running head: Ecological consequences of forest restoration treatments in Colorado

141 established a plot there; if not, we moved on to the next set of coordinates until we had

142 established approximately one plot per 20 ha within each treatment unit. The number of plots per

143 treatment unit ranged from three to 10, and was dependent on the unit's size. We established a

144 similar number and density of plots in paired untreated areas as in the treatment units, using the 145 same selection criteria, at coordinates generated randomly in a GIS.

147 Sampling methods

148 We collected pre-treatment data on plots in the treatment units and untreated areas as described 149 below, in summer 2011. At four of the seven sites, treatments occurred as planned in 2011-12 150 (Table 1), and we collected post-treatment data there in summer 2012. At the remaining three 151 sites, treatments were postponed by one year, and we collected the post-treatment data in those 152 areas in summer 2013. Our final sample size of plots with both pre-treatment data (2011) and 153 post-treatment data (2012 or 2013) was 66 (34 plots located in a total of seven treatment units, 154 and 32 plots in seven nearby untreated areas).

156 Forest stand structure

157 Consistent with the CFRLRI monitoring plan, we established a variable-radius plot (BAF 10) at 158 plot center and measured all 'in' overstory trees that had a diameter at breast height (dbh; breast 159 height $=1.37 \mathrm{~m})$ of at least $2.54 \mathrm{~cm}($ Clement $\&$ Brown 2011; USDA Forest Service 2011). For 160 each tree, we recorded species, dbh, and any indications of wildlife use by tree squirrels (e.g., 161 nests, feeding sign at base). 
Running head: Ecological consequences of forest restoration treatments in Colorado

164 To measure forest structure beyond the scale of the plot, we established a sampling transect

165 running $100 \mathrm{~m}$ north of each plot center. Along this transect, we recorded the distances covered

166 by closed-canopy forest patches and open patches with no canopy cover directly above the

167 transect line. In this context, we defined closed-canopy forest patches (hereafter referred to as

168 "forest patches") as areas containing sapling ( $\geq 1.37 \mathrm{~m}$ tall and $<2.54 \mathrm{~cm} \mathrm{dbh}$ ) or overstory tree

169 canopies, and we defined open patches as areas with no sapling or overstory tree canopies. If

170 canopies were less than $1.5 \mathrm{~m}$ apart, we counted them as part of the same forest patch. Within the

171 forest patches, we noted whether and for what distance the canopy structure was single-storied

172 (i.e. the canopy of only one sapling or overstory tree was present above the transect) or multi-

173 storied (canopies of $>1$ sapling and/or overstory tree were present above the transect). We

174 truncated the data collected along the 100-m transects prior to analyzing the number and mean

175 lengths of open and forest patches, deleting the measurements of the first and last patches

176 measured on each transect because the locations of the plot centers created arbitrary start and end

177 points. We used the full 100-m data for comparisons of the percent of transect length that was in

178 open- versus forest patches, and the percent of transect length within forest patches that had

179 single- versus multi-storied canopy structure.

181 Tree regeneration

182 We counted all regenerating tree seedlings ( $<1.37 \mathrm{~m}$ tall) and saplings present in a 0.002 ha plot

183 (2.5-m radius) around plot center (Clement \& Brown 2011). We identified the species of each 184 regenerating tree and classified its height as $<30 \mathrm{~cm}$ or $\geq 30 \mathrm{~cm}$.

186 Surface fuels 
Running head: Ecological consequences of forest restoration treatments in Colorado

187 We inventoried surface fuels on one 15.2-m transect per plot, which ran north from plot center. 188 We followed standard protocols (Brown 1974), and those of the CFRLRI ( Clement \& Brown 189 2011), to tally all downed woody fuels in four size classes: 1 -hour fuels $(<0.64 \mathrm{~cm}$ diameter $)$ 190 along a 2.54-m section of the transect; $10-\mathrm{hr}$ fuels (0.64 to $2.54 \mathrm{~cm}$ diameter) along a 2.54-m 191 section of the transect; $100-\mathrm{hr}$ fuels (2.54 to $7.62 \mathrm{~cm}$ diameter) along a $3.66-\mathrm{m}$ section of the 192 transect; 1000-hr fuels (>7.62 cm diameter) along the entire 15.2-m length of the transect. We 193 used allometries to convert the tallies into fuel loads for each of the four fuels size classes, and 194 summed these to yield fine fuel (1-hr, 10-hr, and 100-hr fuels) and coarse fuel (1000-hr fuels) 195 loads (Brown 1974). In addition, we measured the depth of the duff layer and fuel bed (litter plus 196 any wood particles present) at two equally spaced points on the transect.

Understory plants and forest floor substrates

199 We measured percent cover of vascular understory plants (i.e., forbs, graminoids, shrubs) and 200 forest floor substrates (e.g., litter, soil, wood by size class) for each plot using a point-intercept 201 method. We established four 9.37-m transects in the cardinal directions from plot center. At 100 202 evenly spaced observation points along each transect, we recorded all forest floor substrates and 203 all understory plants $<1.37 \mathrm{~m}$ tall. While most plant identifications were made to the species 204 level, some identifications could only made only to the genus level due to difficulties 205 distinguishing species when outside peak morphological development; hereafter these 206 identifications are also referred to as species. The number of occurrences of each species and 207 substrate was tallied for each transect to calculate percent cover. We also conducted a complete 208 inventory of all understory species present in a 0.04-ha (11.3-m radius) circular plot positioned at 
Running head: Ecological consequences of forest restoration treatments in Colorado

209

210

211

212 Wildlife use

213 We searched for and recorded sign from two general "guilds" of wildlife (defined here as groups

214 of species that use resources in a similar way; Simberloff \& Dayan 1991) within a 0.04-ha

215 circular plot located at plot center. These were tree-dwelling squirrels (Abert's squirrel, Sciurus

216 aberti, and pine squirrel, Tamiasciurus hudsonicus) and ungulates (mule deer, Odocoileus

217 hemionus, and elk, Cervus canadensis). We tallied sign in numerous categories. For tree

218 squirrels, sign included nests, and feeding sign such as chewed cones, branch clippings, peeled

219 twigs, and middens (Worden \& Kleier 2012); for ungulates, sign included pellets, day beds, and

220 browsing on tree trunks. In data analyses, we included only sign that we classified with a high

221 degree of confidence as fresh or active (based on color, texture, and other indications described

222 in training sessions with local wildlife specialists) in the seasons prior to our initial pre-treatment

223 surveys (fall 2010-summer 2011), and in the same seasons following the treatments (fall 2011-

224 summer 2012 or fall 2012-summer 2013, as applicable; Table 1).

225

226 Statistical analyses

227 We used a Before/After/Control/Impact (BACI) approach to examine the effects of ecological

228 restoration treatments on metrics representing six broad categories: forest stand structure (e.g.,

229 total overstory density (trees per ha; TPH)), forest patch structure (e.g., mean length of forest

230 patches), tree regeneration (e.g., density of ponderosa pine regeneration), forest floor substrates 
Running head: Ecological consequences of forest restoration treatments in Colorado

231 and surface fuels (e.g., fine wood loads), understory plants (e.g., total understory plant richness),

232 and wildlife use (e.g., percent of plots with tree squirrel sign).

234 We used generalized linear mixed models to evaluate the effects of treatment, time, and

235 treatment $\times$ time for each metric. Analyses were conducted in SAS 9.4 with the GLIMMIX

236 procedure (SAS Institute Inc., Cary, North Carolina, USA), and used an $\alpha$ of 0.050 to evaluate

237 significance. Models specified the appropriate distribution for each metric (e.g., negative

238 binomial distribution for metrics such as total TPH, lognormal distribution for metrics such as

239 total overstory basal area (BA), beta distribution for metrics such as total understory plant cover).

240 Site and treatment $\times$ site were included as random effects. Time was included as a random effect

241 with plot as the repeated measures subject and with the two sampling periods for each plot

242 correlated by a compound symmetry covariance structure. For metrics of tree regeneration, forest

243 floor substrates, surface fuels, understory plants, and wildlife use, measurements in untreated and

244 treated plots occurred both pre-and post-treatment, creating four groups in the data (i.e.,

245 untreated plots pre-treatment, untreated plots post-treatment, treated plots pre-treatment, treated

246 plots post-treatment). For these metrics, when treatment $\times$ time was significant, we examined

247 pairwise differences between groups using least squares means with a Tukey-Kramer adjustment.

248 For forest stand structure and forest patch structure metrics, there were only three groups in the

249 data (i.e., untreated plots pre-treatment, treated plots pre-treatment, treated plots post-treatment);

250 we did not measure these metrics in untreated plots post-treatment because of limited funding

251 and time and because they were not expected to show measurable change since pre-treatment

252 surveys. Thus, while we could not evaluate the significance of the treatment $\times$ time interaction 
Running head: Ecological consequences of forest restoration treatments in Colorado

253 term for these metrics, we still examined pairwise differences between groups using least squares

254 means with a Tukey-Kramer adjustment.

\section{Results}

257 Forest stand structure

258 The ecological restoration treatments influenced several forest stand structure metrics (Fig. 2).

259 The treatments caused reductions in both total TPH (46\% average reduction relative to pre-

260 treatment values) and total BA (36\% reduction). Following treatments, the mean percent of TPH

261 and BA represented by ponderosa pine, however, remained around $77 \%(\mathrm{p}=0.996$ and 0.744 ,

262 respectively) and the percent represented by Douglas-fir remained around 17\% ( $\mathrm{p}=0.186$ and $\mathrm{p}$

$263=0.242$, respectively). The quadratic mean diameter (QMD) of both ponderosa pine and of all

264 species in the overstory increased by around $4 \mathrm{~cm}(18 \%)$ post-treatment.

Forest patch structure

267 Several metrics of forest patch structure were also altered by the treatments (Figs. 3 and 4). The

268 percent of transect length comprised of forest patches in treatment units decreased by an average

269 of $45 \%$ following treatments, and there was a corresponding, significant increase in the percent

270 of transect length comprised of open patches. However, the mean number of both open- and

271 forest patches remained relatively constant in treatment units, with between 5 and 6 open- and

272 forest patches per transect, both pre- and post-treatment. The mean length of both the open- and

273 forest patches changed significantly in treated stands. Mean forest patch length decreased by

$27454 \%$, to $5.5 \mathrm{~m}$, and mean open patch length increased by $62 \%$, to $14.3 \mathrm{~m}$. Within forest patches,

275 the mean percent of transect length comprised of single-storied and multi-storied canopy was 
Running head: Ecological consequences of forest restoration treatments in Colorado

276 almost equal prior to treatment, but after treatment, the mean percent of single-storied canopy

277 increased by over a third, to $83 \%$ of forest patch length.

278

279 Tree regeneration

280 Metrics of tree regeneration showed no changes on treated or untreated plots in the first year 281 post-treatment (Table 2). Across all plots and years, 58\% contained seedlings or saplings of any

282 tree species, and the mean density of this regeneration was 3939 stems $^{-1}$. Meanwhile, $41 \%$ of

283 plots contained ponderosa pine regeneration, with a mean of 2200 stems $^{-1}$ found across all

284 plots and years. The mean density of the smallest size class of conifers (<30 cm tall) was 3386

285 stems $\mathrm{ha}^{-1}$ across all plots and years; ponderosa pine represented the majority (54 to $78 \%$ ) of

286 these small seedlings.

287

288 Forest floor substrates and surface fuels

289 The cover of litter/duff, soil, and fine wood on the forest floor was altered by the treatments, but

290 no other metrics of substrate or wood cover, load, or depth were affected (Table 3). Prior to

291 treatment, litter and duff covered $85 \%$ on average of each plot's surface, and following

292 treatments this value dropped by $10 \%$ on treated plots only. Cover of fine wood nearly doubled

293 on treated plots after treatment, from an average of $10 \%$ to $18 \%$, but the loading of fine wood did

294 not likewise change. Soil cover also nearly doubled on treated plots after treatment, from an

295 average of $3 \%$ to $5 \%$.

296

297 Understory plants 
Running head: Ecological consequences of forest restoration treatments in Colorado

Restoration treatments had little impact on understory plant communities in the first posttreatment year (Table 4). Of the 16 understory plant metrics examined here, only one - shrub cover - exhibited a relatively clear treatment effect, with cover on treated plots decreasing from $7 \%$ pre-treatment to $4 \%$ post-treatment. Across all plots and years, plots contained a total of 31 understory species with a total cover of $11 \%$. No single growth form dominated both total richness and cover; total richness was dominated by forbs (63\% of total), while total cover was dominated by shrubs ( $52 \%$ of total). Understory plant communities were, however, highly native-dominated, with native species comprising $94 \%$ of total richness and $95 \%$ of total cover. Furthermore, species with long life spans were considerably more abundant $(88 \%$ and $96 \%$ of total richness and cover, respectively) than those with short life spans. The 5 most commonly encountered species in our plots were the native long-lived forbs pineywoods geranium (Geranium caespitosum), goldenrod species (Solidago spp.), and pussytoes species (Antennaria spp.), and the native long-lived graminoids prairie Junegrass (Koeleria macrantha) and sedge species (Carex spp.).

\section{Wildlife use}

The percentage of plots with signs of recent tree squirrel use decreased one year after treatment, but this decline occurred across both treated and untreated plots (on average, $46 \%$ fewer plots had tree squirrel sign in 2012/13) and thus reflected interannual change rather than change associated with treatments (Table 5). The abundance of tree squirrel sign was quite variable (up to a maximum of 490 freshly harvested cone cobs and needle clippings on one plot) and was also lower across all plots in 2012/13. In contrast, fresh ungulate sign was consistently present on around $25 \%$ of all plots, both pre- and post-treatment. 
Running head: Ecological consequences of forest restoration treatments in Colorado

322 Discussion

323 The ecological restoration treatments in these Colorado Front Range ponderosa pine forests

324 caused marked short-term (i.e., one year post-treatment) changes to several metrics representing

325 forest stand- and patch structure. However, we found little change in other ecological

326 components - few significant increases or decreases were detected in the numerous metrics of

327 tree regeneration, surface fuel loading, understory plant communities, and wildlife use that we

328 examined. Three components of forest floor cover experienced changes, but the degree of change

329 may not have been ecologically significant. To varying extents, these results were in line with

330 the desired effects of the treatments for the Colorado Front Range CFRLRI, and with the

331 findings of other studies. Below we discuss each suite of metrics in turn. We also discuss how

332 this study has contributed to the CFRLRI's adaptive management process, and explore the

333 overall relevance of collaborative monitoring to future forest restoration efforts.

\section{Forest stand structure}

336 We found that treatments caused a mean decrease in TPH of almost 50\%, a mean decrease in BA 337 of almost $40 \%$, and a mean increase of QMD of almost $20 \%$. These changes met the objective of 338 the CFRLRI to reduce forest density, and are within the range of changes made by restoration 339 treatment projects in other ponderosa pine forests (e.g., Fulé et al. 2001, 2006; Waltz et al. 2003; 340 Youngblood et al. 2006; Schwilk et al. 2009; Roccaforte et al. 2010, 2015). Some of these other

341 projects aimed to shift forest conditions towards specific target levels, commonly based on 342 reference conditions representing forest density documented in the area prior to European343 American settlement (e.g., Roccaforte et al. 2010). Although the CFRLRI is quantifying pre- 
Running head: Ecological consequences of forest restoration treatments in Colorado

344

345

346

347

348

349

350

351

352

353

settlement forest density and other overstory metrics in the Front Range to inform further discussion and planning of restoration objectives (e.g., Dickinson 2014; Brown et al. 2015; Battaglia et al. unpublished data), it has not adopted explicit targets at this time. One aspect of treatments did not appear to represent the CFRLRI's current objectives for overstory conditions: the percentage of TPH and BA comprised of ponderosa pine remained constant post-treatment, on average, rather than increasing. Around $60 \%$ of treatment plots had mixed species composition, and of those, approximately half experienced an increase in their percentage of ponderosa pine BA post-treatment (mean $14.2 \pm 3.5 \%$ ) while half experienced a similar decrease in ponderosa BA (mean $14.3 \pm 3.8 \%$ ). Approximately $25 \%$ of treatment plots contained $100 \%$ ponderosa pine both before and after they were thinned, and the remaining $15 \%$ of plots had $100 \%$ ponderosa pine but experienced no change in BA during treatment. In future work, we suggest that both restoration actions and monitoring methods consider starting conditions - and, if possible, the age and canopy status of removed and residual trees - in more detail than was possible within the scope of our study, to permit more focus on the composition, structure, and possible successional trajectories of stands post-treatment.

\section{Forest patch structure}

Following treatments, we found significant increases in the degree of overall openness of stands, and an increase in the mean and variability of length of open patches, but no change in the mean numbers of open- or forest patches. These findings indicate that treatments generally focused on extending the length of existing open patches, causing a corresponding decrease in the length of forest patches - rather than, for example, adding new open patches (which would have led to an increase in the mean number of open patches) or combining existing open patches (which would 
Running head: Ecological consequences of forest restoration treatments in Colorado

367 have led to a decrease in the mean number of open patches). Following treatment, the mean

368 length of forest patches became highly consistent $(6.3 \pm 0.5 \mathrm{~m}$,$) as did the lengths of open$

369 patches (mean $14.3 \pm 2.0 \mathrm{~m}$,), indicating that the treatments created somewhat homogenous stand

370 structure. Implementation therefore likely continued some elements of the regular-spacing

371 prescriptions that were characteristic of traditional fuels reduction treatments on NFs in the Front

372 Range, rather than meeting the CFRLRI's objective to increase heterogeneity in stand structure

373 (Underhill et al. 2014; Dickinson et al. 2015). The collection and interpretation of data, both

374 historic and current, on spatial configuration of trees and openings within stands is a relatively

375 new area of work within the forest restoration community (e.g., Sanchez Meador et al. 2009;

376 Larson \& Churchill 2012; Churchill et al. 2013; Tuten et al. 2015; Dickinson et al. 2016) but is

377 motivated by extensive evidence that spatial patterns of forest canopy at diverse scales affect

378 processes such as fire, hydrologic cycles, seed dispersal, understory development, and wildlife

379 habitat use (Larson \& Churchill 2012 and references therein.) Our novel transect sampling

380 method allowed us to quantify some aspects of spatial stand structure beyond the scale of plots in

381 a more rapid and cost-effective manner than the detailed stem- or stand-mapping conducted in

382 spatial pattern analyses; this may prove useful in other monitoring efforts (see Davis et al. 2016;

383 Dickinson et al. 2016).

385 Treated stands had significantly less multi-storied stand structure $(\sim 15 \%)$ than untreated or pre-

386 treatment stands $(\sim 50 \%)$, raising some concerns within the CFRLRI. Although multi-storied

387 forest patches have often been viewed as containing undesired 'ladder fuels' that traditional fuels

388 reduction treatments aimed to remove, more recent ecological restoration prescriptions for

389 uneven-aged management suggest retaining more multi-storied groups of trees, interspersed with 
Running head: Ecological consequences of forest restoration treatments in Colorado

openings of variable sizes that would not be likely to carry high-severity crown fire across uncharacteristically large areas (Larson \& Churchill 2012; Churchill et al. 2013). Some multistoried patches might experience torching if an ignition occurred, but if enough interstitial treeless openings and low density stands were present, this stand structure would be expected to promote desired outcomes such as a mosaic of fire behavior and effects (Churchill et al. 2013); resilience to disturbances such as insect epidemics that often target certain size classes or species of trees (Fettig \& McKelvey 2014); and retention of diverse habitat in the multi-storied patches for certain species of wildlife (e.g., Germaine et al. 2004; Fontaine \& Kennedy 2012). In conjunction with field trips and examination of aerial imagery, our data helped CFRLRI silviculturists adapt some aspects of treatment prescriptions to increase the heterogeneity of posttreatment forest structure instead of simplifying it (Jeff Underhill, USFS, Denver, Colorado, personal communication).

\section{Tree regeneration}

There were no significant effects of treatment on tree regeneration, which was not unexpected in the first post-treatment year. Ponderosa pine has episodic regeneration patterns throughout its range (Cooper 1960; Bailey \& Covington 2002; Shepperd et al. 2006) and there were no years during the time period of our study with the combinations of high cone production and adequate precipitation patterns that facilitate establishment of seedlings (Shepperd et al. 2006; Flathers et al. 2016). Conversely, we found no evidence that treatments were associated with mortality of existing seedlings on our plots. Other studies of ponderosa regeneration patterns after forest thinning in Colorado (Shepperd et al. 2006; Ertl 2015), as well as in Arizona (Bailey \& Covington 2002; Puhlick et al. 2011), Montana (Fajardo et al. 2007), and New Mexico (Thomas 
Running head: Ecological consequences of forest restoration treatments in Colorado

413 \& Waring 2014), have found significantly greater densities in thinned stands versus unthinned

414 stands. However, these studies occurred later post-treatment than our study, providing more time

415 for trees to respond to changes in growing conditions and for any treatment effects (e.g. patterns

416 of establishment versus mortality) to become apparent. Although the CFRLRI has not yet

417 identified objectives for tree regeneration, the current density of ponderosa pine regeneration that

418 we measured on treated plots was more than twice the minimum of 470 seedlings ha ${ }^{-1}$

419 recommended for 'stocking' in ponderosa forests of the Front Range, and the percentage of

420 treated plots with ponderosa pine regeneration that we found - 35\% - may increase over time to

421 the level of $70 \%$ that is specified in current forest management plans as a post-treatment

422 objective after three to five years (PSICC 1984; ARP 1997).

423

$424 \quad$ Forest floor substrates and surface fuels

425 Litter is very abundant in Colorado Front Range ponderosa pine forests, and although its cover 426 on plots decreased significantly after treatments, its depth did not change and the decrease in 427 cover from $85 \%$ to $75 \%$ may not be ecologically significant. Soil exposure experienced a

428 similarly modest increase, from $3 \%$ to 5\%, which may limit opportunities for the post-treatment 429 establishment of understory plants and ponderosa pine seedlings (Cooper et al. 1960; Xiong \& 430 Nilsson 1999; Bonnet et al. 2005). Desired conditions for cover of litter and soil have not yet 431 been addressed by the CFRLRI. Percent cover of another forest floor layer, fine wood, nearly 432 doubled as a result of the treatments, consistent with the results of a recent meta-analysis that 433 found increases in surface fuels after thinning treatments in many dry conifer forest types (Fulé 434 et al. 2012). However, we did not also find statistically significant changes in fine fuel loads, 435 suggesting that either fine wood biomass did not increase along with wood cover, or that our 
Running head: Ecological consequences of forest restoration treatments in Colorado

measurement protocols for fine fuel loads were not sensitive enough to detect some potentially ecologically significant changes. In fact, we noted considerable amounts of new downed wood in 31 of the 34 treated plots $(91 \%)$ after treatment, in the form of tree boles, slash, and/or chips (Fig. 1). However, these new pieces of wood fell on our single fuels transect in only 10 of 34 plots (29\%). We suggest using more extensive sampling and/or more thorough methods to document changes in fuel loading in future (e.g. Keane \& Gray 2013), given the CFRLRI's objective that treatments should either reduce, or at least not increase, the abundance of fine or coarse downed wood in stands (Clement and Brown 2011).

\section{Understory plants}

Understory plant metrics of richness and cover were largely unimpacted by restoration treatments in the first post-treatment year. This finding is in agreement with similar short-term (1-2 years post-treatment) studies that have been conducted in dry conifer forests of the Colorado Front Range (Ertl 2015) and elsewhere in the US (Abella \& Springer 2015 and references therein). To some extent, this lack of change may be considered in line with CFRLRI project objectives (Clement \& Brown 2011); for example, treatments did not promote an undesirable increase in the (already low) abundance of exotic plants, and did not negatively affect understory plant diversity. Furthermore, longer-term (5+ years post-treatment) studies commonly document an increase in many understory plant metrics as understory plants respond to the reduction in competition with overstory trees, suggesting that we may see positive understory plant responses in our plots in the future (Laughlin et al. 2006; Thomas \& Waring 2014; Abella \& Springer 2015 and references therein; Ertl 2015; Fornwalt et al. 2017). Longer-term post-treatment increases in metrics such as native species richness and cover would be viewed as furthering CFRLRI project 
Running head: Ecological consequences of forest restoration treatments in Colorado

objectives, while increases in other metrics, particularly exotic species richness and cover, would not be. It is critical to continue monitoring these plots so that the longer-term effectiveness of the treatments can be evaluated.

\section{Wildlife use}

For tree squirrels, metrics of use changed significantly with time but not with treatment; for ungulates, the percentage of plots with recent sign remained consistent across treatment and time. These results support those of other studies in similar forest types, both those that found annual changes in occupancy by tree squirrels (e.g. Wampler et al. 2008; Worden \& Kleier 2012) and those that found consistent use of treated areas by ungulates (Germaine et al. 2004; Thomas and Waring 2014). However, given the large spatial and long temporal scales at which wildlife species respond to changes in habitat structure, food supply, and abiotic factors (Kalies et al. 2010), it is likely premature to evaluate whether treatments have met the CFRLRI's general objective that treatments promote, or at least do not reduce, the occurrence of native wildlife species expected to use restored forest habitat (Clement \& Brown 2011). Our findings demonstrated to concerned stakeholders in the CFRLRI that tree squirrels and ungulates did not avoid treated areas of the forest, but our monitoring methods did not permit a full evaluation of these species' abundance, behavior, or distribution. Recently, more detailed studies of Abert's squirrel, for example, have identified variations in post-treatment habitat use associated with many factors (season, year, and distinct attributes of trees or overstory; Dodd et al. 2006; Loberger et al. 2011; Worden \& Kleier 2012; Yarborough et al. 2015), suggesting that focused monitoring of this ponderosa pine-obligate species over longer time frames may be warranted to evaluate any changes in its use of forests treated by the CFRLRI. 
Running head: Ecological consequences of forest restoration treatments in Colorado

This study's contribution to the adaptive management process of the CFRLRI

484 485

486

487

488

489

490

491

492

493

494

495

496

497

498

499

500

501

502

503

504

Taken together, our results suggest that these restoration treatments in the Colorado Front Range achieved, in the first year, progress toward several of the desired conditions and trends identified by the CFRLRI as management goals (Clement \& Brown 2011; Underhill et al. 2014; Dickinson et al. 2015). However, as described above, some of our results suggested the need for modification of restoration treatment prescriptions in an active adaptive management framework (DeLuca et al. 2010, Aplet et al. 2014). For certain metrics, such as forest stand structure, prescriptions have indeed been adapted over time to foster greater variability in treated stands, although this is an ongoing process (Underhill et al. 2014; Dickinson et al. 2015) that has also benefited from recent stand reconstruction surveys that identified more open and heterogeneous historic forest conditions than those we measured post-treatment (Dickinson 2014; Brown et al. 2015; Battaglia et al., USFS Fort Collins, unpublished data). In general, our study represented successful effectiveness monitoring, and helped catalyze important discussions by the CFRLRI of shared objectives for restoration, monitoring, decision-making, and thresholds for action in the adaptive management process (Aplet et al. 2014).

A primary contribution of our study to adaptive management was in the 'adaptive monitoring' sub-process of the cycle (Lindenmayer \& Likens 2009, 2010; Aplet et al. 2014). By catalyzing at least three important expansions and revisions of the CFLRI's monitoring protocol, this project exemplified several hallmarks of successful adaptive monitoring. First, our adoption of a BACI study design that included untreated areas highlighted the fact that some metrics - such as understory plants, wildlife habitat use, and tree regeneration - can change annually, which may 
Running head: Ecological consequences of forest restoration treatments in Colorado

505 506

preclude a valid assessment of treatment effects from comparisons made only between pre- and post-treatment data in treated areas (Block et al. 2001; Larson et al. 2013). Our BACI framework and results set an important precedent for comparative monitoring of changes in untreated areas, which the CFRLRI has continued. Second, we identified metrics and methods that have been adopted as longer-term components of an expanded monitoring program funded by the CFRLRI. Our data on understory plants, in particular, spurred the CFRLRI to develop additional questions and plans for the monitoring of understory plants, and our general methodology was applied across a much larger spatial scale beginning in 2015. Finally, the methods that we suspected were not adequate for a valid assessment of metrics of interest have been revised either moderately (in the case of surface fuels) or significantly (a greatly expanded program of wildlife monitoring began in 2014). If our study had not developed additional monitoring efforts complementary to the initial efforts of the CFRLRI, it is possible that several important metrics might not have been addressed or measured until much later in the lifecycle of the CFLR program.

\section{The role of landscape-scale collaborative restoration projects in fostering resilient forests} Although short-term, this study's inclusion of a diverse suite of ecological metrics in its evaluation of CFLR treatments represents a valuable contribution to collaborative efforts to incorporate science into restoration-focused management of dry conifer forests of the western US (Allen et al. 2002; Larson et al. 2013). Monitoring to evaluate both the intended ecological effects of treatments, and any unanticipated negative consequences (Hutto \& Belote 2013), will be critical as innovative, broad-scale restoration efforts like the CFLR have increasing impacts across forest landscapes (DeLuca et al. 2010; Schultz et al. 2014; Davis et al. 2016; JCLRP 
Running head: Ecological consequences of forest restoration treatments in Colorado

542 time.

\section{Acknowledgements}

545 We thank the members of the CFRLRI for their input and collaboration. We appreciate the 546 logistical support and field site access provided by Jeff Underhill, Ed Biery, Chris Oliver, Dave 547 Hattis, Kevin Zimlinghaus, Adam Messing, Chad Julian, Felix Quesada, Nick Stremel, Susan 548 Spaulding, John Staight, Casey Cooley, and Janelle Valladares. We thank field assistants Peter 549 Pavlowich, Stephanie Asherin, Abigail Smith, Danny Volz, Matt Thomas, Rebecca Harris, 550 Kristen Doyle, Akasha Faist, and Colton Heeney. We appreciate statistical analysis assistance 
Running head: Ecological consequences of forest restoration treatments in Colorado

from James zumBrunnen and Scott Baggett, and comments from Rick Truex and Jay

Diffendorfer on earlier drafts of the manuscript. This study was initiated with a grant from the

Southern Rockies Landscape Conservation Cooperative, as well as with funding from Boulder

County Parks and Open Space, the Land Change Science program of the US Geological Survey, and the USFS Rocky Mountain Research Station.

\section{Literature cited}

Abella SR, Springer JD (2015) Effects of tree cutting and fire on understory vegetation in mixed conifer forests. Forest Ecology and Management 335:281-299

Allen CD, Savage M, Falk DA, Suckling KF, Swetnam TW, Schulke T, Stacey PB, Morgan P, Hoffman M, Klingel JT (2002) Ecological restoration of Southwestern ponderosa pine ecosystems: A broad perspective. Ecological Applications 12:1418-1433

Aplet G, Brown P, Briggs J, Mayben S, Edwards D, Cheng T (2014) Collaborative implementation of forest landscape restoration in the Colorado Front Range. Colorado Forest Restoration Institute, Colorado State University, Technical Brief CFRI-TB-1403, Fort Collins, Colorado

ARP [Arapaho and Roosevelt National Forest and Pawnee National Grassland] (1997) Revision of the Land and Resource Management Plan. US Department of Agriculture, Forest Service, Arapaho and Roosevelt National Forest and Pawnee National Grassland, Fort Collins, Colorado, USA.

Bailey JD, Covington WW (2002) Evaluating ponderosa pine regeneration rates following ecological restoration treatments in northern Arizona, USA. Forest Ecology and Management 155:271-278

Bhandary U, Muller B (2009) Land use planning and wildfire risk mitigation: an analysis of wildfire-burned subdivisions using high-resolution remote sensing imagery and GIS data. Journal of Environmental Planning and Management 52: 939-955

Block WA, Franklin AB, Ward JP, Ganey JL, White GC (2001) Design and implementation of monitoring studies to evaluate the success of ecological restoration on wildlife. Restoration Ecology 9:293-303

Bonnet VH, Schoettle AW, Shepperd WD (2005) Postfire environmental conditions influence the spatial pattern of regeneration for Pinus ponderosa. Canadian Journal of Forest Research 35:37-47

Brown JK (1974) Handbook for inventorying downed woody material. U.S. Department of Agriculture Forest Service General Technical Report INT-16, Intermountain Forest and Range Experiment Station, Ogden, Utah

Brown PM, D'Amico DR, Carpenter AT, Andrews DM (2001) Restoration of montane ponderosa pine forests in the Colorado Front Range: a forest ecosystem management plan for the city of Boulder. Ecological Restoration 19:19-26

Brown PM, Battaglia MA, Fornwalt PJ, Gannon B, Huckaby LS, Julian C, Cheng AS (2015) Historical (1860) forest structure in ponderosa pine forests of the northern Front Range, 
Running head: Ecological consequences of forest restoration treatments in Colorado

Colorado. Canadian Journal of Forest Research 45:1462-1473

Chambers ME, Fornwalt PJ, Malone SL, Battaglia M (2016) Patterns of conifer regeneration following high severity wildfire in ponderosa pine-dominated forests of the Colorado Front Range. Forest Ecology and Management 378:57-67

Cheng AS, Gerlak AK, Dale L, Mattor K (2015) Examining the adaptability of collaborative governance associated with publicly managed ecosystems over time: insights from the Front Range Roundtable, Colorado, USA. Ecology and Society 20:35-48

Churchill DJ, Larson AJ, Dahlgreen MC, Franklin JF, Hessburg PF, and Lutz JA (2013) Restoring forest resilience: From reference spatial patterns to silvicultural prescriptions and monitoring. Forest Ecology and Management 291:442-457

Clement J, Brown PM (2011) Front Range Roundtable, Collaborative Forest Landscape Restoration Project 2011: Ecological, Social, and Economic Monitoring Plan. Colorado Forest Restoration Institute, Colorado State University, Fort Collins, Colorado

Converse SJ, White GC, Farris KL, Zack S (2006) Small Mammals and Forest Fuel Reduction: National-Scale Responses to Fire and Fire Surrogates. Ecological Applications 16:17171729

Cooper CF (1960) Changes in Vegetation, Structure, and Growth of Southwestern Pine Forests since White Settlement. Ecological Monographs 30:130-164

Covington WW, Fulé PZ, Moore MM, Hart SC, Kolb TE, Mast JN, Sackett SS, Wagner MR (1997) Restoration of ecosystem health in southwestern ponderosa pine forests. Journal of Forestry 95:23-29

Culver S, Dean C, Patten F, Thinnes J (2001). Upper South Platte Watershed Protection and Restoration Project. Proceedings of RMRS-P-22: 110-117. US Department of Agriculture, Forest Service, Rocky Mountain Research Station, Fort Collins, Colorado

Davis CR, Belote RT, Williamson MA, Larson AJ, Esch BE (2016) A rapid forest assessment method for multiparty monitoring across landscapes. Journal of Forestry 114:125-13

DeLuca TH, Aplet GH, Wilmer B, Burchfield J (2010) The unknown trajectory of forest restoration: A call for ecosystem monitoring. Journal of Forestry 108:288-295

Dickinson Y (2014) Landscape restoration of a forest with a historically mixed-severity fire regime: What was the historical landscape pattern of forest and openings? Forest Ecology and Management 331:264-271

Dickinson YL, Addington R, Aplet G, Babler M, Battaglia M, Brown P, Cheng A, Cooley C, Edwards D, Feinstein J, Fornwalt P, Gibbs H, Matonis M, Pelz K, Regan C (2015) Desirable forest structures for a restored Front Range. Technical Brief CFRI-TB-1402, Colorado Forest Restoration Institute, Colorado State University, Fort Collins, Colorado Dickinson Y, Pelz K, Giles E, Howie J (2016) Have we been successful? Monitoring horizontal forest complexity for forest restoration projects. Restoration Ecology 24:8-17

Dodd NL, Schweinsburg RE, Boe S (2006) Landscape-scale forest habitat relationships to tasseleared squirrel populations: Implications for ponderosa pine forest restoration. Restoration Ecology 14:537-547

Ertl E (2015) Restoration impacts on understory plant species in a Colorado Front Range ponderosa pine and Douglas-fir forest. Master of science thesis, Colorado State University, Fort Collins, Colorado

Fajardo A, Graham JM, Goodburn JM, Fiedler CE (2007) Ten-year responses of ponderosa pine growth, vigor, and recruitment to restoration treatments in the Bitterroot Mountains, Montana, USA. Forest Ecology and Management 243:50-60 
Running head: Ecological consequences of forest restoration treatments in Colorado

Fettig CJ, McKelvey SR (2014) Resiliency of an interior ponderosa pine forest to bark beetle infestations following fuel-reduction and forest-restoration treatments. Forests 5:153-176

Flathers KN, Kolb TE, Bradford JB, Waring KM, Moser, WK 2016. Long-term thinning alters ponderosa pine reproduction in northern Arizona. Forest Ecology and Management. 374: 154-165.

Fontaine JB, Kennedy PL (2012) Meta-analysis of avian and small-mammal response to fire severity and fire surrogate treatments in U.S. fire-prone forests. Ecological Applications 22:1547-1561

Fornwalt PJ, Kaufmann M R, Stohlgren TJ (2010) Impacts of mixed severity wildfire on exotic plants in a Colorado ponderosa pine-Douglas-fir forest. Biological Invasions 12: 26832695

Fornwalt PJ, Rocca ME, Battaglia MA, Rhoades CC, Ryan MG. 2017. Mulching treatments promote understory plant communities in three Colorado coniferous forest types. Forest Ecology and Management. In press.

FRFTP [Front Range Fuels Treatment Partnership] (2006) Living with fire: Protecting communities and restoring forest health. http://frontrangeroundtable.org/Published_Documents.php (accessed 12 December 2015)

Fulé PZ, Waltz AE, Covington WW, Heinlein TA (2001) Measuring forest restoration effectiveness in reducing hazardous fuels. Journal of Forestry 99:24-29

Fulé PZ, Covington WW, Stoddard MT, Bertolette D (2006) 'Minimal-impact' restoration treatments have limited effects on forest structure and fuels at Grand Canyon, USA. Restoration Ecology 14:357-368

Fulé PZ, Crouse JE, Roccaforte JP, Kalies EL (2012) Do thinning and/or burning treatments in western USA ponderosa or Jeffrey pine-dominated forests help restore natural fire behavior? Forest Ecology and Management 269:68-81

Germaine SS, Germaine HL, Boe SR (2004) Characteristics of mule deer day-bed and forage sites in current-condition and restoration-treated ponderosa pine forest. Wildlife Society Bulletin 32:554-564

Hessburg PF, Churchill DJ, Larson AJ, Haugo RD, Miller C, Spies TA, North MP, Povak NA, Belote RT, Singleton PH, Gaines WL, Keane RE, Aplet GH, Stephens SL, Morgan P, Bisson PA, Rieman BE, Salter RB, Reeves GH (2015) Restoring fire-prone Inland Pacific landscapes: seven core principles. Landscape Ecology 30:1805-1835

Hunter ME, Shepperd WE, Lentile LB, Lundquist JE, Andreu MG, Butler JL, Smith FW (2007) A comprehensive guide to fuels treatment practices for ponderosa pine in the Black Hills, Colorado Front Range, and Southwest. Paper 14, Joint Fire Science Program Synthesis Reports

Hutto RL, Belote RT (2013) Distinguishing four types of monitoring based on the questions they address. Forest Ecology and Management 289:183-189

JCLRP 2016 [Joint Chiefs' Landscape Restoration Partnership], US Department of Agriculture. http://www.nrcs.usda.gov/wps/portal/nrcs/detail/national/newsroom/features/?cid=stelprd b1244394 (accessed 30 June 2016)

Jolly WM, Cochrane MA, Freeborn PH, Holden ZA, Brown TJ, Williamson GJ, Bowman DM (2015) Climate-induced variations in global wildfire danger from 1979 to 2013. Nature Communications 6:7537.

Kalies EL, Chambers CL, Covington WW (2010) Wildlife responses to thinning and burning treatments in southwestern conifer forests: A meta-analysis. Forest Ecology and 
Running head: Ecological consequences of forest restoration treatments in Colorado

Management 259:333-342.

Keane RE, Gray K (2013) Comparing three sampling techniques for estimating fine woody down dead biomass. International Journal of Wildland Fire 22: 1093-1107

Keely WH, Germaine SS, Stanley TR, Spaulding SE, Wanner CE (2013) Response of brownheaded cowbirds and three host species to thinning treatments in low-elevation ponderosa pine forests along the northern Colorado Front Range. Forest Ecology and Management 306 (2013) 226-233

Korb JE, Fulé PZ, Stoddard MT (2012) Forest restoration in a surface fire-dependent ecosystem: An example from a mixed conifer forest, southwestern Colorado, USA. Forest Ecology and Management 269:10-18

Larson AJ, Churchill D (2012) Tree spatial patterns in fire-frequent forests of western North America, including mechanisms of pattern formation and implications for designing fuel reduction and restoration treatments. Forest Ecology and Management 267:74-92

Larson AJ, Belote RT, Williamson MA, Aplet GH (2013) Making monitoring count: Project design for active adaptive management. Journal of Forestry 111:348-356

Laughlin DC, Moore MM, Bakker JD, Casey CA, Springer JD, Fulé PZ, Covington WW (2006) Assessing targets for the restoration of herbaceous vegetation in ponderosa pine forests. Restoration Ecology 14:548-560

League K, Veblen T (2006) Climatic variability and episodic Pinus ponderosa establishment along the forest-grassland ecotones of Colorado. Forest Ecology and Management 228:98-107

Lindenmayer DB, Likens GE (2009) Adaptive monitoring: a new paradigm for long-term research and monitoring. Trends in Ecology and Evolution 24:482-486

Lindenmayer DB, Likens GE (2010) The science and application of ecological monitoring. Biological Conservation 143:1317-1328

Loberger CD, Theimer TC, Rosenstock SS, Wightman CS (2011) Use of restoration-treated ponderosa pine forest by tassel-eared squirrels. Journal of Mammalogy 92:1021-1027

Moore MM, Fulé PZ, Covington WW (1999) Reference conditions and ecological restoration: a southwestern ponderosa pine perspective. Ecological Applications 9:1266-1277

Moore, MM, Casey CA, Bakker JD, Springer JD, Fulé PZ, Covington WW, and Laughlin DC. 2006. Herbaceous vegetation responses (1992-2004) to restoration treatments in a ponderosa pine forest. Rangeland Ecology and Management 59:135-144.

North MP, Stephens SL, Collins BM, Agee JK, Aplet G, Franklin JF, Fulé PZ (2015) Reform forest management. Science 349:1280-1281

NRCS [Natural Resources Conservation Service] (2016) The PLANTS Database, National Plant Data Center, Baton Rouge, Louisiana. http://plants.usda.gov (accessed 3 May 2016)

Pistorius T, Freiberg H (2014) From Target to Implementation: Perspectives for the International Governance of Forest Landscape Restoration. Forests 5:482-497

PSICC [Pike and San Isabel National Forests and Comanche and Cimarron National Grasslands] (1984) Land and Resource Management Plan. US Department of Agriculture, Forest Service, Pike and San Isabel National Forests and Comanche and Cimarron National Grasslands, Pueblo, Colorado, USA

Reynolds RT, Sanchez Meador, AJ, Youtz JA, Nicolet T, Matonis MS, Jackson PL, DeLorenzo DG, Graves AD (2013) Restoring composition and structure in Southwestern frequentfire forests: A science-based framework for improving ecosystem resiliency. US Department of Agriculture, Forest Service, General Technical Report RMRS-GTR-310. 
Running head: Ecological consequences of forest restoration treatments in Colorado

Rocky Mountain Research Station, Fort Collins, Colorado

Rhoades CC, Entwistle D, Butler D (2011) The influence of wildfire extent and severity on streamwater chemistry, sediment and temperature following the Hayman Fire, Colorado. International Journal of Wildfire Science 20:430-442

Robichaud PR, Rhee H, Lewis SA (2014) A synthesis of post-fire Burned Area Reports from 1972 to 2009 for western US Forest Service lands: trends in wildfire characteristics and post-fire stabilization treatments and expenditures. International Journal of Wildland Fire. 23: 929-944

Roccaforte JP, Huffman DW, Fulé PZ, W. W. Covington WW, Chancellor WW, Stoddard MT, Crouse JE (2015) Forest structure and fuels dynamics following ponderosa pine restoration treatments, White Mountains, Arizona, USA. Forest Ecology and Management 337:174-185

Schultz CA, Jedd T, Beam RD (2012) The Collaborative Forest Landscape Restoration Program: A history and overview of the first projects. Journal of Forestry 110:381-391

Schultz CA, Coelho DL, Beam RD (2014) Design and governance of multiparty monitoring under the USDA Forest Service's Collaborative Forest Landscape Restoration Program. Journal of Forestry 112:198-206

Schwilk DW, Keeley JK, Knapp EE, McIver J, Bailey JD, Fettig CJ, Fiedler CE, Harrod RJ, Moghaddas JJ, Outcalt KW, Skinner CN, Stephens SL, Waldrop TA, Yaussy DA, Youngblood A (2009) The national Fire and Fire Surrogate study: Effects of fuel reduction methods on forest vegetation structure and fuels. Ecological Applications 19:285-304

SER [Society for Ecological Restoration International] (2004) Primer on ecological restoration. http://www.ser.org (accessed 3 June 2016)

Smith AMS, Kolden CA, Paveglio TB, Cochrane MA, Bowman DMJS, Moritz MA, Kliskey AD, Alessa L, Hudak AT, Hoffman CM, Lutz JA, Queen LP, Goetz SJ, Higuera PE, Boschetti L, Flannigan M, Yedinak KM, Watts AC, Strand EK, Van Wagtendonk JW, Anderson JW, Stocks BJ, and Abatzoglou JT (2016) The science of firescapes: Achieving fire-resilient communities. BioScience 66:130-146

Stephens SL, McIver JD, Boerner RJE, Fettig CJ, Fontaine JB, Hartsough BR, Kennedy PL, Schwilk DW (2012) The effects of forest fuel-reduction treatments in the United States. BioScience 62:549-560

Stephens SL, Lydersen JM, Collins BM, Fry DL, Meyer MD (2015) Historical and current landscape-scale ponderosa pine and mixed conifer forest structure in the Southern Sierra Nevada. Ecosphere 6:79

Stewart-Oaten A, Murdoch WW, Parker KR (1986) Environmental impact assessment: "Pseudoreplication" in time? Ecology 67:929-940

Thomas Z, Waring KM (2015) Enhancing resiliency and restoring ecological attributes in second-growth ponderosa pine stands in northern New Mexico, USA. Forest Science 61:93-104

Underhill JL, Dickinson Y, Rudney A, Thinnes J (2014) Silviculture of the Colorado Front Range landscape restoration initiative. Journal of Forestry 112:484-493

USDA Forest Service Natural Resource Management Field Sampled Vegetation Common Stand Exam (CSE) User's Guide Manual for Region 2. 2011. https://www.fs.fed.us/nrm/documents/fsveg/cse_user_guides/R2FG.pdf. Accessed 10 July 2011 
Running head: Ecological consequences of forest restoration treatments in Colorado

775

776

777

778

779

780

781

782

783

784

Westerling, AL, Hidalgo, HG, Cayan, DR, Swetnam, TW (2006) Warming and earlier spring increase western U.S. forest wildfire activity. Science. 313: 940-94

Worden KJ, Kleier C (2012) Impact of thinning ponderosa pines (Pinus ponderosa) on populations of Abert's squirrels (Sciurus aberti). The Southwestern Naturalist, 57:380384

Yarborough RF, Gist JA, Loberger CD, Rosenstock SS (2015) Habitat use by Abert's squirrels (Sciurus aberti) in managed forests. The Southwestern Naturalist 60:166-170

Youngblood A, Metlen KL, Coe K (2006) Changes in stand structure and composition after restoration treatments in low elevation dry forests of northeastern Oregon. Forest Ecology and Management 234:143-163 
Running head: Ecological consequences of forest restoration treatments in Colorado

Table 1. Attributes of seven Colorado Front Range study sites at which forest restoration treatments were implemented in ponderosa pine forests in 2011-13. At each site, a diverse suite of metrics was measured in treated and untreated plots before and one year after treatment.

\begin{tabular}{|c|c|c|c|c|c|c|}
\hline Study site & $\begin{array}{l}\text { Treatment } \\
\text { description }\end{array}$ & $\begin{array}{l}\text { Treatment } \\
\text { date }\end{array}$ & $\begin{array}{c}\text { Treatment } \\
\text { area (ha) }\end{array}$ & $\begin{array}{l}\text { Elevation } \\
\text { (m) }\end{array}$ & $\begin{array}{l}\text { \# of } \\
\text { treated } \\
\text { plots }\end{array}$ & $\begin{array}{c}\text { \# of } \\
\text { untreated } \\
\text { plots }\end{array}$ \\
\hline \multicolumn{7}{|c|}{ Heil Ranch (Boulder County Parks and Open Space) } \\
\hline Heil 5 & $\begin{array}{l}\text { Mechanical thinning, } \\
\text { with slash lopped and } \\
\text { scattered }\end{array}$ & $\begin{array}{c}\text { Winter } \\
\text { 2012-13 }\end{array}$ & 50 & 1960 & 6 & 5 \\
\hline Heil 7 & $\begin{array}{l}\text { Mechanical thinning, } \\
\text { with slash lopped and } \\
\text { scattered }\end{array}$ & $\begin{array}{l}\text { Winter } \\
2012-13\end{array}$ & 70 & 2100 & 4 & 4 \\
\hline \multicolumn{7}{|c|}{ Estes Valley (Roosevelt National Forest) } \\
\hline Estes Valley 13 & $\begin{array}{l}\text { Hand thinning, with } \\
\text { some mastication }\end{array}$ & $\begin{array}{l}\text { Spring } \\
2012\end{array}$ & 20 & 2480 & 3 & 3 \\
\hline Estes Valley 28 & $\begin{array}{l}\text { Hand thinning, with } \\
\text { slash piled and burned }\end{array}$ & $\begin{array}{l}\text { Winter } \\
2011-12\end{array}$ & 50 & 2420 & 5 & 4 \\
\hline Estes Valley 34 & $\begin{array}{l}\text { Hand thinning, with } \\
\text { slash piled and burned }\end{array}$ & $\begin{array}{l}\text { Winter } \\
2011-12\end{array}$ & 10 & 2160 & 3 & 3 \\
\hline \multicolumn{7}{|c|}{ Phantom Creek (Pike National Forest) } \\
\hline Phantom Creek 1 & $\begin{array}{l}\text { Mechanical thinning, } \\
\text { with most slash } \\
\text { removed }\end{array}$ & $\begin{array}{c}\text { Summer } \\
2011\end{array}$ & 60 & 2740 & 3 & 5 \\
\hline Phantom Creek 2 & $\begin{array}{l}\text { Mechanical thinning, } \\
\text { with most slash } \\
\text { removed }\end{array}$ & $\begin{array}{c}\text { Summer } \\
2011\end{array}$ & 150 & 2630 & 10 & 8 \\
\hline
\end{tabular}


Running head: Ecological consequences of forest restoration treatments in Colorado

Table 2. Means (and standard errors) of tree regeneration metrics before and one year after restoration treatments in ponderosa pine forests of the Colorado Front Range; $n=34$ treated plots and $n=32$ untreated plots in seven treatment units and seven nearby untreated areas. No interactions of treatment $x$ time were significant for any metric at $\alpha=0.050$, so pairwise comparisons between groups were not performed.

\begin{tabular}{|c|c|c|c|c|c|c|c|}
\hline \multirow[t]{2}{*}{ Metric } & \multicolumn{2}{|c|}{ Untreated } & \multicolumn{2}{|c|}{ Treated } & Treatment & Time & $\begin{array}{c}\text { Treatment } \\
\times \text { Time }\end{array}$ \\
\hline & Pre & Post & Pre & Post & \multicolumn{3}{|c|}{ P-value } \\
\hline Density (stems $h^{-1}$ ) & & & & & & & \\
\hline All regeneration & 5579 (1940) & $4911(2076)$ & $2823(868)$ & $2442(731)$ & 0.542 & 0.651 & 0.977 \\
\hline Ponderosa pine & 3559 (1399) & $2595(987)$ & $1404(601)$ & $1243(567)$ & 0.648 & 0.576 & 0.516 \\
\hline Douglas-fir & $1740(1040)$ & $2113(1595)$ & $790(339)$ & $629(362)$ & 0.250 & 0.922 & 0.480 \\
\hline Conifers $<30 \mathrm{~cm}$ tall & $5175(1914)$ & $4553(2051)$ & $2018(750)$ & $1799(690)$ & 0.547 & 0.728 & 0.980 \\
\hline
\end{tabular}


Running head: Ecological consequences of forest restoration treatments in Colorado

Table 3. Means (and standard errors) of forest floor substrate and surface fuel metrics before and one year after restoration treatments in ponderosa pine forests of the Colorado Front Range; $n=34$ treated plots and $n=32$ untreated plots in seven treatment units and seven nearby untreated areas. For metrics where treatment $\times$ time was significant, pairwise comparisons between groups were evaluated using least squares means; values sharing letters were not statistically different $(\alpha=0.050)$.

\begin{tabular}{|c|c|c|c|c|c|c|c|}
\hline \multirow[t]{2}{*}{ Metric } & \multicolumn{2}{|c|}{ Untreated } & \multicolumn{2}{|c|}{ Treated } & \multirow[t]{2}{*}{ Treatment } & \multirow{2}{*}{$\begin{array}{c}\text { Time } \\
\text { P-value }\end{array}$} & \multirow[t]{2}{*}{$\begin{array}{c}\text { Treatment } \\
\times \text { Time }\end{array}$} \\
\hline & Pre & Post & Pre & Post & & & \\
\hline \multicolumn{8}{|c|}{ Forest floor substrate cover (\%) } \\
\hline $\begin{array}{l}\text { Litter/duff } \\
\text { Fine wood } \\
\text { Coarse wood } \\
\text { Soil }\end{array}$ & $\begin{array}{c}85.3(1.5)^{\mathrm{ab}} \\
11.9(2.0)^{\mathrm{ac}} \\
1.6(0.3)^{\mathrm{a}} \\
3.0(0.9)^{\mathrm{a}}\end{array}$ & $\begin{array}{c}82.5(1.5)^{\mathrm{ab}} \\
7.3(0.9)^{\mathrm{b}} \\
1.3(0.3)^{\mathrm{a}} \\
3.0(0.9)^{\mathrm{a}}\end{array}$ & $\begin{array}{c}85.0(1.5)^{\mathrm{a}} \\
10.4(1.0)^{\mathrm{ab}} \\
1.5(0.2)^{\mathrm{a}} \\
3.0(0.7)^{\mathrm{a}}\end{array}$ & $\begin{array}{c}75.3(1.7)^{\mathrm{b}} \\
18.3(2.0)^{\mathrm{c}} \\
2.3(0.4)^{\mathrm{a}} \\
4.9(0.8)^{\mathrm{b}}\end{array}$ & $\begin{array}{l}0.256 \\
0.083 \\
0.294 \\
0.760\end{array}$ & $\begin{array}{r}<\mathbf{0 . 0 0 1} \\
0.589 \\
0.492 \\
0.050\end{array}$ & $\begin{array}{c}0.012 \\
<0.001 \\
0.026 \\
0.044\end{array}$ \\
\hline $\begin{array}{l}\text { Surface fuel la } \\
\text { Fine wood } \\
\text { Coarse wood }\end{array}$ & $\begin{array}{l}\left.h a^{-1}\right) \\
\quad 1.4(0.2) \\
\quad 1.8(0.6)\end{array}$ & $\begin{array}{l}1.0(0.2) \\
1.5(0.5)\end{array}$ & $\begin{array}{l}1.6(0.3) \\
2.4(0.6)\end{array}$ & $\begin{array}{l}1.3(0.2) \\
2.2(0.5)\end{array}$ & $\begin{array}{l}0.476 \\
0.271\end{array}$ & $\begin{array}{l}0.299 \\
0.750\end{array}$ & $\begin{array}{l}0.833 \\
0.596\end{array}$ \\
\hline $\begin{array}{l}\text { Surface fuel } d \\
\text { Duff } \\
\text { Fuel bed }\end{array}$ & n) $\begin{array}{l}1.2(0.2) \\
4.6(0.5)\end{array}$ & $\begin{array}{l}2.1(0.3) \\
3.3(0.4)\end{array}$ & $\begin{array}{l}1.0(0.1) \\
4.0(0.4)\end{array}$ & $\begin{array}{l}2.1(0.3) \\
3.2(0.5)\end{array}$ & $\begin{array}{l}0.936 \\
0.820\end{array}$ & $\begin{array}{l}0.281 \\
\mathbf{0 . 0 0 4}\end{array}$ & $\begin{array}{l}0.890 \\
0.666\end{array}$ \\
\hline
\end{tabular}


Running head: Ecological consequences of forest restoration treatments in Colorado

Table 4. Means (and standard errors) of understory plant metrics before and one year after restoration treatments in ponderosa pine forests of the Colorado Front Range; $n=34$ treated plots and $n=32$ untreated plots in seven treatment units and seven nearby untreated areas. For metrics where treatment $\times$ time was significant, pairwise comparisons between groups were evaluated using least squares means; values sharing letters were not statistically different $(\alpha=0.050)$.

\begin{tabular}{|c|c|c|c|c|c|c|c|}
\hline \multirow[t]{2}{*}{ Metric } & \multicolumn{2}{|c|}{ Untreated } & \multicolumn{2}{|c|}{ Treated } & Treatment & Time & $\begin{array}{c}\text { Treatment } \\
\times \text { Time } \\
\end{array}$ \\
\hline & Pre & Post & Pre & Post & \multicolumn{3}{|c|}{ P-value } \\
\hline \multicolumn{8}{|c|}{ Richness (species $0.04 \mathrm{ha}^{-1}$ ) } \\
\hline Total plant & $32.4(1.3)$ & 31.4 (1.5) & $29.3(1.1)$ & $30.3(1.5)$ & 0.753 & 0.840 & 0.333 \\
\hline Forb & $21.0(0.8)$ & $19.3(0.9)$ & $18.1(0.9)$ & $19.0(1.0)$ & 0.154 & 0.470 & 0.020 \\
\hline Graminoid & $5.9(0.5)$ & $6.5(0.6)$ & $5.8(0.5)$ & $6.3(0.6)$ & 0.759 & 0.075 & 0.738 \\
\hline Shrub & $4.9(0.3)$ & $4.9(0.4)$ & $4.4(0.4)$ & $4.3(0.4)$ & 0.159 & 0.546 & 0.546 \\
\hline Exotic plant & $1.3(0.3)$ & $1.4(0.4)$ & $1.4(0.4)$ & $2.0(0.6)$ & 0.907 & 0.412 & 0.305 \\
\hline Native plant & $30.9(1.1)$ & $29.9(1.2)$ & $27.6(1.0)$ & $28.1(1.1)$ & 0.077 & 0.694 & 0.189 \\
\hline Short-lived plant & $3.2(0.6)^{a}$ & $2.5(0.6)^{\mathrm{b}}$ & $2.4(0.4)^{a b}$ & $3.6(0.8)^{\mathrm{ab}}$ & 0.752 & 0.243 & 0.007 \\
\hline Long-lived plant & $28.6(1.1)$ & $28.1(1.2)$ & $25.9(0.9)$ & $26.0(0.9)$ & 0.106 & 0.721 & 0.587 \\
\hline \multicolumn{8}{|l|}{ Cover (\%) } \\
\hline Total plant & $13.3(1.8)$ & $13.0(1.7)$ & $11.1(1.3)$ & $8.7(1.2)$ & 0.091 & 0.088 & 0.166 \\
\hline Forb & $2.2(0.6)$ & $2.2(0.5)$ & $1.4(0.2)$ & $1.3(0.3)$ & 0.079 & 0.792 & 0.863 \\
\hline Graminoid & $4.0(0.7)$ & $4.1(0.7)$ & $3.0(0.5)$ & $3.3(0.7)$ & 0.195 & 0.654 & 0.846 \\
\hline Shrub & $7.1(1.4)^{\mathrm{a}}$ & $6.7(1.3)^{\mathrm{ab}}$ & $6.5(1.1)^{\mathrm{a}}$ & $3.9(0.7)^{b}$ & 0.173 & $<0.001$ & $<0.001$ \\
\hline Exotic plant & $0.6(0.4)$ & $0.6(0.3)$ & $0.3(0.2)$ & $0.3(0.1)$ & 0.671 & 0.601 & 0.651 \\
\hline Native plant & $12.6(1.8)$ & $12.3(1.6)$ & $10.7(1.3)$ & $8.3(1.1)$ & 0.096 & 0.074 & 0.135 \\
\hline Short-lived plant & $0.6(0.3)$ & $0.6(0.3)$ & $0.1(0.0)$ & $0.3(0.2)$ & 0.901 & 0.153 & 0.232 \\
\hline Long-lived plant & $12.7(1.8)$ & $12.4(1.7)$ & $10.9(1.3)$ & $8.2(1.1)$ & 0.105 & 0.050 & 0.110 \\
\hline
\end{tabular}


Running head: Ecological consequences of forest restoration treatments in Colorado

Table 5. Means (and standard errors) of wildlife use metrics before and one year after restoration treatments in ponderosa pine forests of the Colorado Front Range; $n=34$ treated plots and $n=32$ untreated plots in seven treatment units and seven nearby untreated areas. Values represent fresh or active signs of use recorded for 2 guilds of species (tree squirrels and ungulates). No interactions of treatment $\times$ time were significant for any metric at $\alpha=0.050$, so pairwise comparisons between groups were not performed.

\begin{tabular}{|c|c|c|c|c|c|c|c|}
\hline \multirow{2}{*}{ Metric } & \multicolumn{2}{|c|}{ Untreated } & \multicolumn{2}{|c|}{ Treated } & \multirow[t]{2}{*}{ Treatment } & \multirow{2}{*}{$\begin{array}{c}\text { Time } \\
\text { P-value }\end{array}$} & \multirow[t]{2}{*}{$\begin{array}{c}\text { Treatment } \\
\times \text { Time }\end{array}$} \\
\hline & Pre & Post & Pre & Post & & & \\
\hline \multicolumn{8}{|l|}{ Plots with sign (\%) } \\
\hline Tree squirrels & $93.8(4.3)$ & $65.6(8.5)$ & $70.6(7.9)$ & $26.5(7.7)$ & 0.060 & $<0.001$ & 0.828 \\
\hline Ungulates & $25.0(7.8)$ & $21.9(7.4)$ & $23.5(7.4)$ & $29.4(7.9)$ & 0.625 & 0.862 & 0.524 \\
\hline \multicolumn{8}{|c|}{ Number of signs $\left(0.04 h a^{-1}\right)$} \\
\hline Tree squirrels & $66.1(12.7)$ & $27.8(8.3)$ & $29.7(12.1)$ & $23.4(14.7)$ & 0.159 & 0.010 & 0.612 \\
\hline
\end{tabular}


Running head: Ecological consequences of forest restoration treatments in Colorado

Figure 1. Representative treated plots before (top) and one year after (bottom) restoration treatments in ponderosa pine forests of the Colorado Front Range.

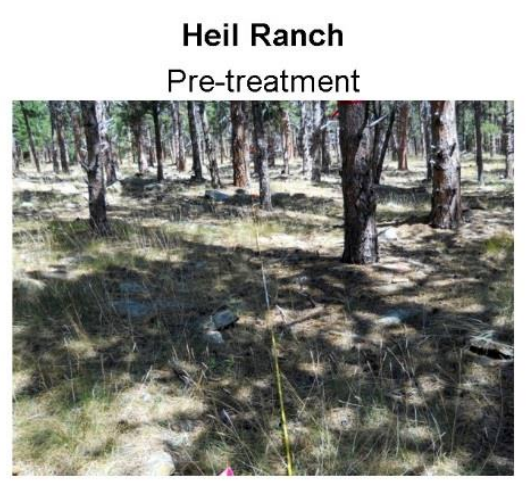

Post-treatment

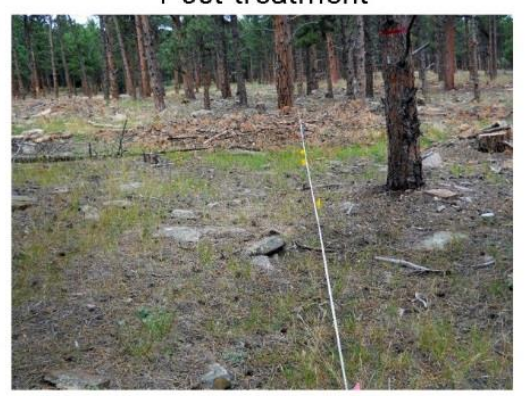

Estes Valley

Pre-treatment

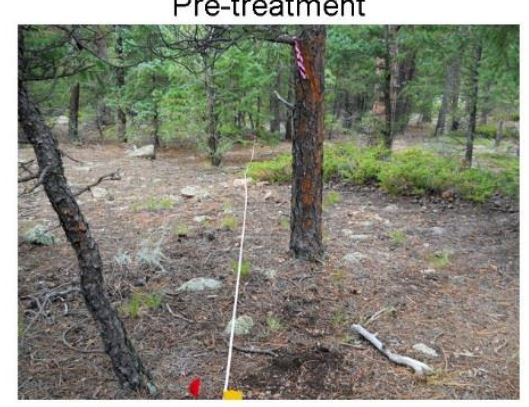

Post-treatment

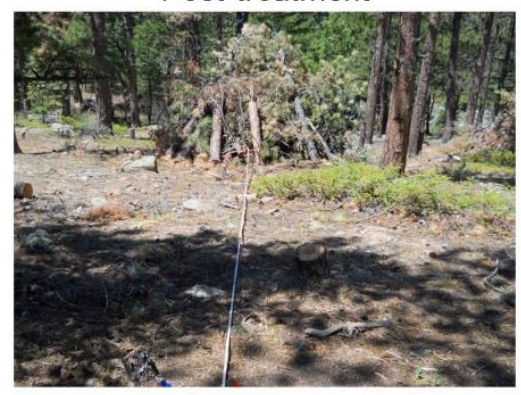

Phantom Creek

Pre-treatment
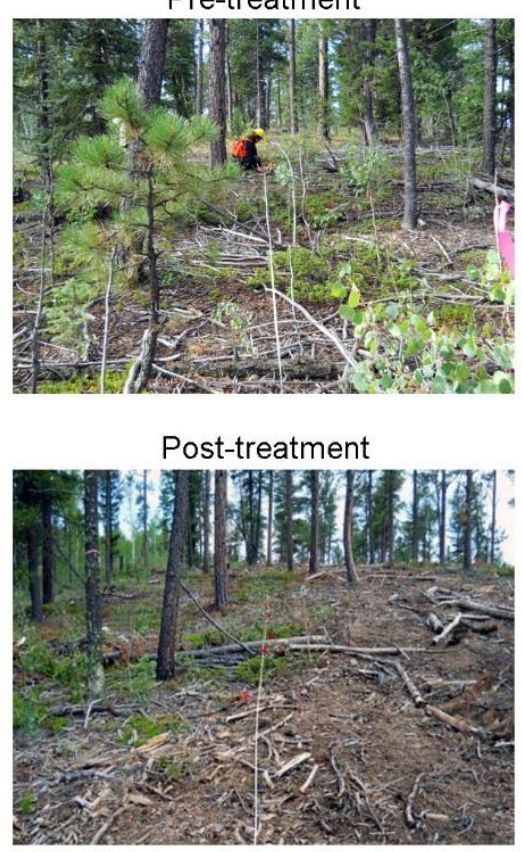
Running head: Ecological consequences of forest restoration treatments in Colorado

Figure 2. Mean live overstory (a) density (stems (trees) per ha), (b) basal area, and (c) quadratic mean diameter in ponderosa pine forests of the Colorado Front Range that experienced restoration treatments in 2011-13. Data were collected at 34 treated plots and 32 untreated plots in seven treatment units and seven nearby untreated areas. Untreated plots were measured pre-treatment and treated plots were measured preand post-treatment. Values for density and basal area are further differentiated for ponderosa pine (PIPO), Douglas-fir (PSME) and other species (e.g., aspen, blue spruce, subalpine fir); standard errors are for all species combined. Box-and-whisker diagrams for quadratic mean diameter show the mean (dashed line), median (solid middle line), 25th and 75th percentile (solid bottom and top line), and 10th and 90th percentile (bottom and top whiskers) values. For each metric, groups that share letters were not significantly different $(\alpha=0.050)$.
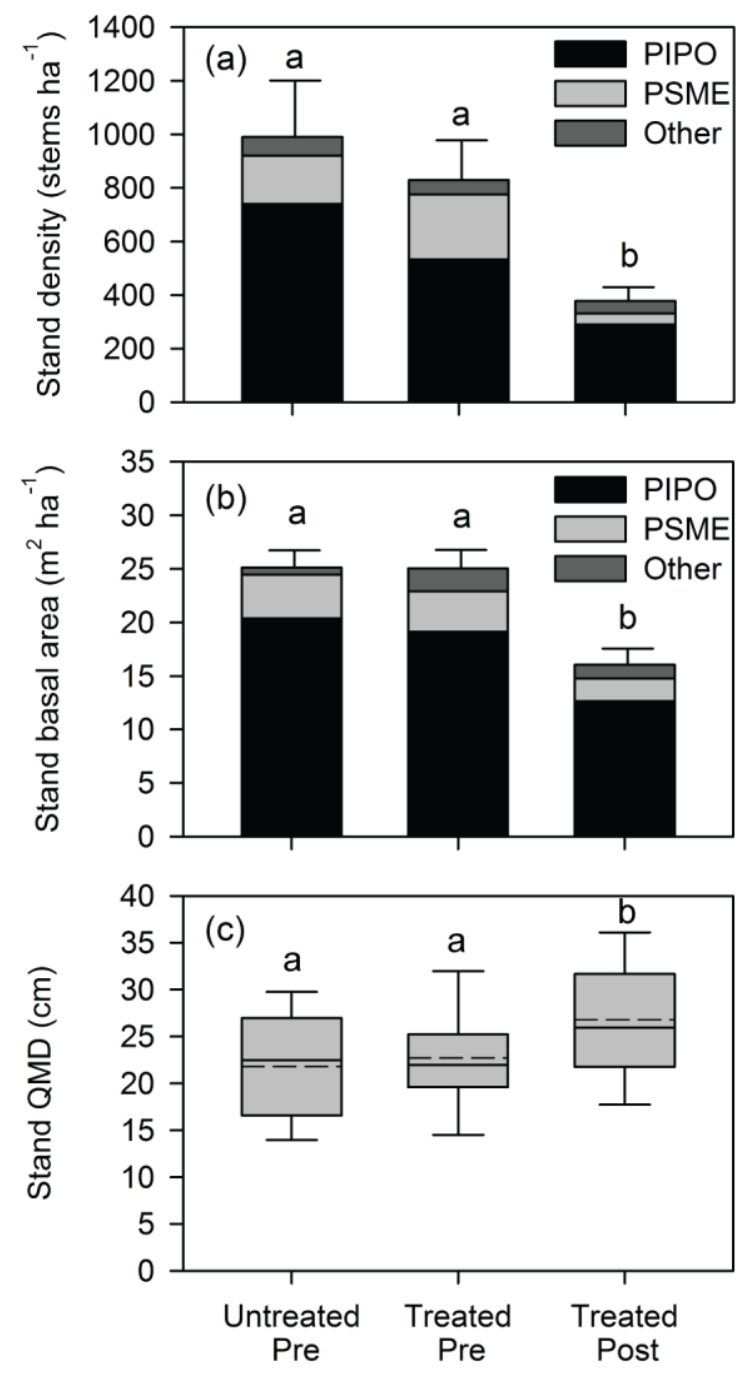
Running head: Ecological consequences of forest restoration treatments in Colorado

Figure 3. Attributes of (a, b, c) forest patches and (d, e, f) openings (i.e., unforested patches) along 100-m transects in ponderosa pine forests of the Colorado Front Range that experienced restoration treatments in 2011-13. Transects in treatment units $(n=33)$ were measured pre- and post-treatment, and transects in untreated areas $(n=32)$ were measured pre-treatment. Box-and-whisker diagrams show the mean (dashed line), median (solid middle line), 25th and 75th percentile (solid bottom and top line), and 10th and 90th percentile (bottom and top whiskers) values. For each metric, groups that share letters were not significantly different $(\alpha=0.050)$.
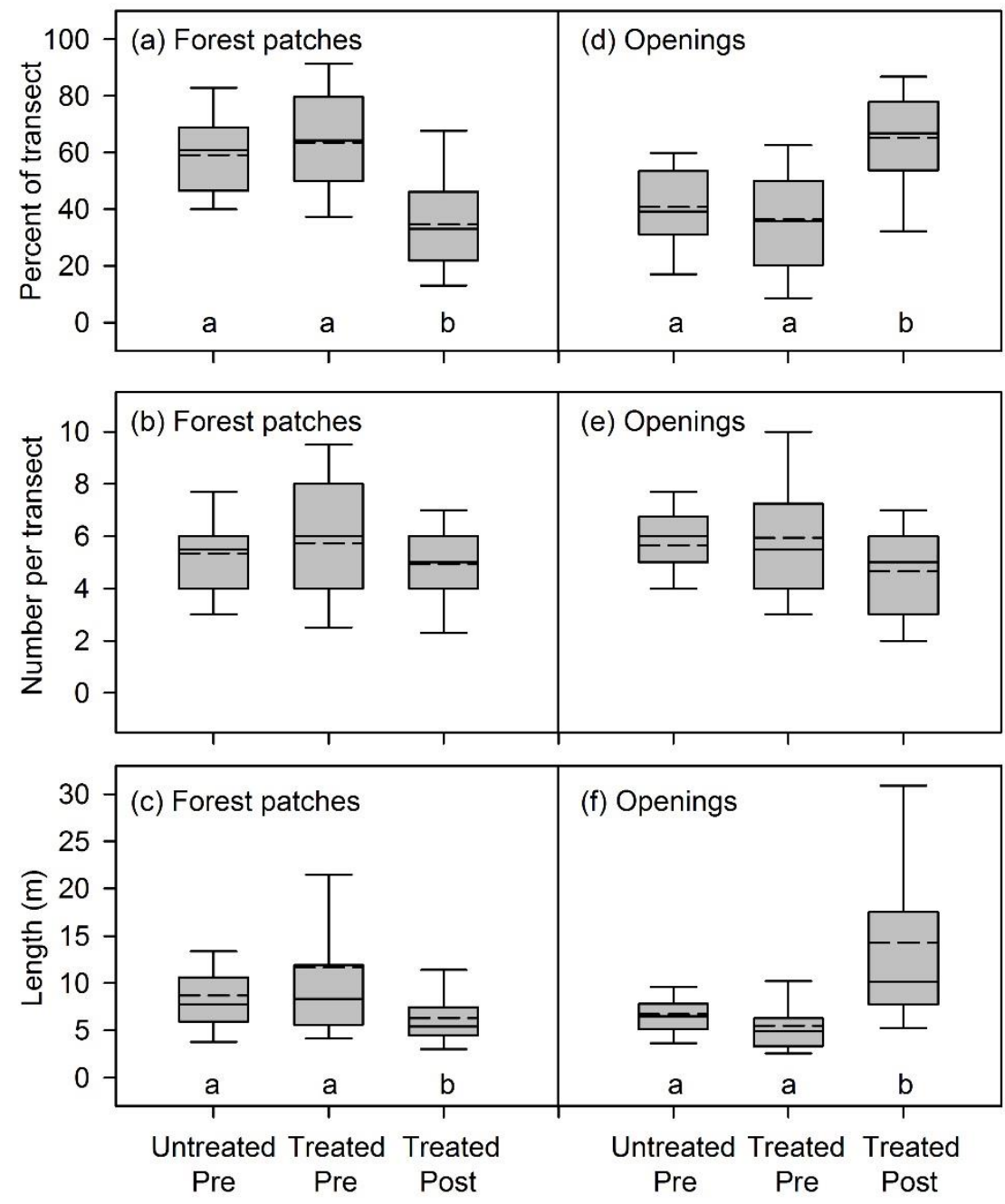
Running head: Ecological consequences of forest restoration treatments in Colorado

Figure 4. The percent of the forest patches (see Figure 3) along 100-m transects that had (a) single-storied and (b) multi-storied canopy structure in ponderosa pine forests of the Colorado Front Range that experienced restoration treatments in 2011-13. Transects in treatment units $(n=33)$ were measured preand post-treatment, and transects in untreated areas $(n=32)$ were measured pre-treatment. Box-andwhisker diagrams show the mean (dashed line), median (solid middle line), 25th and 75th percentile (solid bottom and top line), and 10th and 90th percentile (bottom and top whiskers) values. For each metric, groups that share letters were not significantly different $(\alpha=0.050)$.

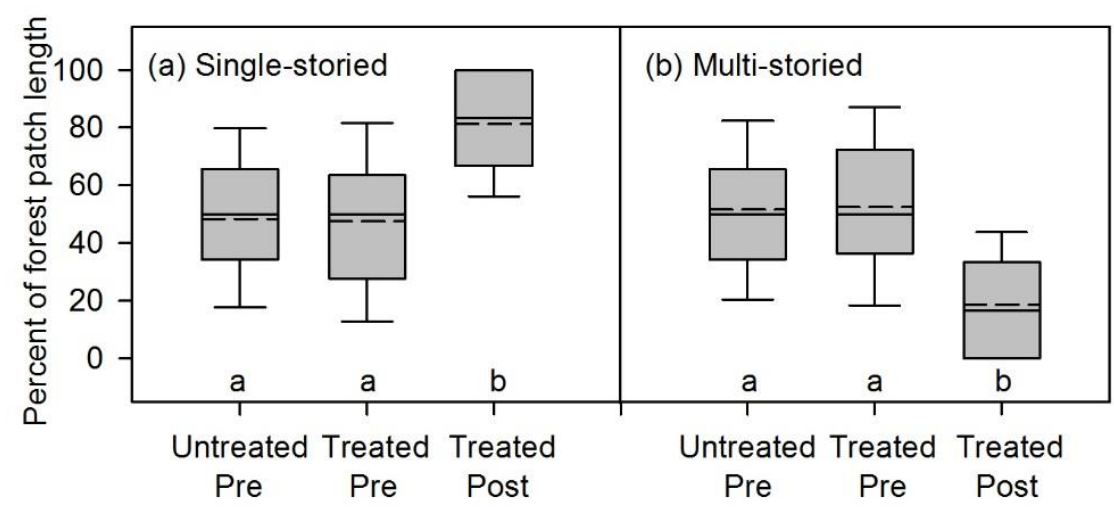

